\section{Weight loss counseling for dialysis patients to prepare for transplant}

\author{
Karen F Factor* \\ Renal Dietitan, Duke University Hospital, 5104 Greyfield Boulevard, Durham, NC 27713, USA
}

Obesity has become a worldwide Epidemic affecting more than 300 million people. Overweight is defined as BMI (Body Mass Index) of $25-29.9 \mathrm{~kg} / \mathrm{m} 2$. Obesity is defined as BMI greater than $30 \mathrm{~kg} / \mathrm{m} 2$, and Morbid Obesity is a BMI of $>$ than $35 \mathrm{~kg} / \mathrm{m} 2$ [1].

Many Dialysis patients are overweight. Dialysis patients that are labeled morbidly obese based on BMI, may not be able to be listed on the Transplant list. Some Dialysis Clinics require a BMI less than $35 \mathrm{~kg} / \mathrm{m} 2$ and some require a BMI $<$ than $40 \mathrm{~kg} / \mathrm{m} 2$. Hence, many obese dialysis patients are asked to lose weight, and we all know that Renal Transplant provides a better quality of life [2].

Because each transplant center may use different criteria for eligibility, patients and members of the dialysis team should be aware of the BMI criteria for the referral transplant center. Patients who are not eligible for the transplant due to obesity should receive counseling emphasizing a healthy lifestyle and weight loss [3].

Successful weight management requires a multidisciplinary approach encompassing health care team members. They consist of the following: Renal Dietitian, Social Workers, Nurse, Exercise Physiologist and a Physician [6].

\section{Counseling patients}

Renal patients need counseling from their Renal Dietitian. (RD), and they need to be in close contact with their patients. Programs with a high success rate consist of RD's meeting with the patient weekly, then tapering down to monthly visits. The RD needs to counsel on weight loss by providing either tips on weight loss, or a regimented 1200-2000 kcal renal diet. It is important for the patient to keep a food log so the patient can monitor his intake, and it has been found that those that keep food logs have greater success. Also an online App such as MyFitnessPal.com is good for those who have apps [4].

In order to promote lasting dietary behavior changes many Registered Dietitians/Nutritionists (RDN's) are progressing

\section{More Information}

*Address for Correspondence: Karen F Factor, Renal Dietitan, Duke University Hospital, 5104 Greyfield Boulevard, Durham, NC 27713, USA, Tel: 919-599-6467; Email: karenfactor@nc.rr.com

Submitted: 15 July 2019

Approved: 30 August 2019

Published: 02 September 2019

How to cite this article: Factor KF. Weight loss counseling for dialysis patients to prepare for transplant. J Clini Nephrol. 2019; 3: 161-163.

DOI: dx.doi.org/10.29328/journal.jcn.1001042

Copyright: @ 2019 Factor KF. This is an open access article distributed under the Creative Commons Attribution License, which permits unrestricted use, distribution, and reproduction in any medium, provided the original work is properly cited

Check for updates

from advice-giving roles to client-centered counseling methods. Motivational interviewing (MI) is another form of counseling which can increase intrinsic motivation and reduce ambivalence to change and it respects the client's autonomy. MI is based on the following key principles:

1. Expressing Empathy.

2. Developing discrepancy.

3. Rolling with resistance.

4. Supporting self-efficacy.

Motivational Interviewing encompasses collaborating ideas to evoke change, and respecting clients' autonomy. It consists of open-ended questions, reflections, affirmations and summaries. These are used throughout the session [7].

\section{Calculating energy requirements}

Body weight can be difficult to determine in Chronic Kidney Disease patients because as kidney function declines the ability to eliminate excess fluid is lost. The body weight recorded and monitored over time should be the estimated dry weight or "edema-free body weight" as defined by KDOQI. For hemodialysis patients this weight should be obtained after dialysis and for peritoneal dialysis patients, it is the weight after the drainage of dialysate with the peritoneum empty. Weight loss should be assessed and provided in terms of percent weight loss by using the following equation: Weight Loss $=\{($ UBW-Actual Body Weight $/$ UBW $) \times 100$. 
If the patient is just starting dialysis, the percent of weight due to fluid removal needs to be established [8].

KDOQI recommends daily energy intake for Maintenance HD and chronic PD Patients younger than 60 years of age which is $35 \mathrm{kcal} / \mathrm{kg} / \mathrm{d}$, and for patients greater than 60 years 30 to $35 \mathrm{kcal} / \mathrm{kg} /$ of body weight is recommended. But for patients on a weight loss diet clinical judgment is needed, and $25-30 \mathrm{kcal} / \mathrm{kg} / \mathrm{d}$ is recommended [8].

Adjusted Body weight needs to be calculated for patients who have $25 \%$ of excess body weight above ideal body weight (IBW) less than $25 \%$ is metabolically active tissue. Therefore, it is recommended that an adjusted body weight be utilized to calculate energy needs. The formulas is the following: Adjusted Body weight $(\mathrm{kg})=\mathrm{IBW}+($ Actual BWIdeal BW $x$ 0.25) [8].

\section{Exercise}

Exercise is important if a patient wants to decrease weight. RDN's need to discuss Physical Activity (PA) goals, which work for the patient, and are approved by a Physician. Depending on how much Physical Activity the patient is able to do along with compliance with diet, can determine how much weight per week the patient will lose [7].

\section{Case Study}

Mrs. $\mathrm{R}$ is a 32-year-old woman who has just started Peritoneal Dialysis. When patient was with CKD Stage 3, she attended the Pre-ESRD class and received information on the Renal Diet, and her weight was $113.3 \mathrm{~kg}$ and BMI was 42.9 $\mathrm{kg} / \mathrm{m} 2$. She also did the Optifast diet before starting PD at her Fitness Center and lost $7.2 \mathrm{~kg}$. Weight decreased to $106.1 \mathrm{k}$ $/ \mathrm{m} 2$. and BMI decreased to $40.3 \mathrm{~kg} / \mathrm{m} 2$. She wants to get a Kidney Transplant and was told that she needs to decrease weight to a BMI less than $35 \mathrm{~kg} \mathrm{~m} 2 / \mathrm{kg}$.

\section{Assessment}

\begin{tabular}{|c|}
\hline Box 1 \\
\hline Past Medical History \\
\hline Morbid Obesity with BMI of $40-42.8 \mathrm{~kg} / \mathrm{m} 2$ \\
\hline Anemia \\
\hline ESRD \\
\hline Lupus \\
\hline
\end{tabular}

Meds: Omega 3, Colace, Zofran, Klocron $20 \mathrm{mEq}$ once a day, 2 Phoslo with meals, and Diflucan.

Table 1: Anthropometrics.

\begin{tabular}{|c|c|}
\hline \multicolumn{2}{|c|}{ Anthropometrics } \\
\hline Height: & $162.6 \mathrm{~cm} \mathrm{(5"4")}$ \\
\hline Weight: & $106.1 \mathrm{~kg}(234 \mathrm{lb})$ \\
\hline BMI & $40.13 \mathrm{~kg} / \mathrm{m} 2$ \\
\hline Frame Size: & Large \\
\hline Ideal Body Weight: & $52.9-66.1 \mathrm{~kg}$ \\
\hline Adjusted Ideal Body weight & $76.1 \mathrm{~kg}(167 \mathrm{lb})$ \\
\hline \% Of Adjusted Ideal Body weight: & $139 \%$ \\
\hline
\end{tabular}

\begin{tabular}{|c|c|}
\hline Table 2: Laboratory Tests. & \\
\hline \multicolumn{2}{|c|}{ Laboratory Tests } \\
\hline Calcium: & $9.5 \mathrm{mg} / \mathrm{dL}$ \\
\hline Phosphorus: & $4.5 \mathrm{mg} / \mathrm{dL}$ \\
\hline Parathyroid Hormone: & $126 \mathrm{pg} / \mathrm{m} 2$ \\
\hline Albumin: & $2.6 \mathrm{~g} / \mathrm{dL}$ \\
\hline Potassium: & $4.2 \mathrm{mmol} / \mathrm{L}$ \\
\hline
\end{tabular}

\section{Estimation of Nutrient Needs:}

Calories: Adjusted IBW: $76.1 \mathrm{~kg}$ x 25-30 = 1902.5-2283 kcal

Protein: Adjusted IBW $76.1 \mathrm{~kg}$ x 1.2-1.3 = 91.3-98.9 grams

\section{4 hour Diet Recall:}

Breakfast: Ensure 1 can

Morning snack: none

Lunch: Caesar salad

Afternoon snack: none

Supper: Cheese.

Personal pan pizza, 8 oz Ginger a

Evening snack: none

Total kcal: 1272; Total Protein: 44 grams; Total CHO: 148 grams; Total Fat: 56 grams.

Evaluation: Diet recall reveals patient with insufficient protein and kcal intake. Diet is poorly balanced as consists of $46 \% \mathrm{CHO}, 14 \%$ protein, and $40 \%$ fat. Goal was set to decrease weight to $84 \mathrm{~kg}$ (185 lbs.) (Total of $22.4 \mathrm{~kg}-27 \%$ )in 1year at $1 / 2$ to $1 \mathrm{~kg}$ per week.

Patient was counseled on a $20000 \mathrm{kcal} 90$-gram protein diet and a one-week food record was provided.

\section{Nutrition diagnosis}

- Altered nutrition-related laboratory values related to Renal failure and insufficient protein intake as evidenced by albumin low at 2.6 and diet recall.

- NC-3.3 Overweight/obesity related to poor eating habits as evidenced by BMI high at $40.2 \mathrm{~kg} / \mathrm{m} 2$.

\section{Nutrition Intervention}

Nutrition Prescription? $2000 \mathrm{kcal}, 90$ gram protein weight loss diet [5]

\section{Monitoring and Evaluation}

Met with patient in person twice the first month and spoke over the phone twice that month. Than after that met with patient once a month. Albumin increased from 2.6 to 3.3. 
Patient succeeded with weight loss, and weight decreased from $106.1 \mathrm{~kg}$ (233 lb) to $84 \mathrm{~kg}(185 \mathrm{lb})$ in 14 months and BMI decreased to $33.68 \mathrm{~kg} / \mathrm{m} 2$ and patient was put transplant list.

\section{Conclusion}

Patients with Morbid Obesity need Weight Loss counseling to decrease their BMI to less than $35 \mathrm{~kg} / \mathrm{m} 2$ to be listed for Transplant. Sticking with a Weight Loss program is difficult, so RDN's need to be in close contact with their patients. Using MI and supporting an exercise program, which a Physician approves, can make a difference and enable patients to reach their goals.

\section{References}

1. Rahimlu M, Shab-Bidar S, Djafarian K. Body Mass Index and allcause Mortality in Chronic Kidney Disease: A Dose-response MetaAnalysis of Observational Studies. J Ren Nutr. 2017; 27: 225-232. PubMed: https://www.ncbi.nlm.nih.gov/pubmed/28625526
2. Kalentar-Zadeh $\mathrm{K}$. High BMI and Kidney Transplant Wait listing. AM J Transplant: 2011; 11: 725.

3. Johansen K. Obesity and body composition for transplant wait-list candidacy-challenging or maintaining the BMI limits? J Ren Nutr. 2013; 23: 207-209.

PubMed: https://www.ncbi.nlm.nih.gov/pmc/articles/PMC3635042/

4. Foster GD, Makris AP, Bailer BA. Behavioral Treatment of Obesity. Am J Clin Nutr. 2005; 82: 230-S \& 235-S.

PubMed: https://www.ncbi.nlm.nih.gov/pubmed/16002827

5. McCarthy, Maureen P. Chronic Kidney Disease and the Nutrition Care Process. Academy of Nutrition and Dietetics. 2014; 99-100/69/37.

6. Hickel S. Weight Management Tips for Patients on Hemodialysis. J Ren Nutr. 2010; 20: e21-22.

7. Smart H, Clifford D, Morris NM. Nutrition Students Gain Skills from Motivational Interviewing Curriculum. Journal of Academy of Nutrition and Dietetics. 2014; 114: 1712.

8. Byham-Gray L, Stover J, Wiesen K. A Clinical Guide to Nutrition Care in Kidney Disease. Academy of Nutrition and Dietetics. 2013; 9, 10, 56; 76. 